\title{
PENGARUH EDUKASI MANFAAT BAWANG PUTIH TERHADAP KEPUTUSANMENGKONSUMSI BAWANG PUTIH PADA PENDERITA HIPERTENSI DI PUSKESMAS KARYA WANITA PEKANBARU
}

\author{
Sri Yanti ${ }^{1)}$, Iyang Maisi Fitriani ${ }^{2)}$, Fitriani ${ }^{3)}$ \\ ${ }^{1}$ Program Studi S1 Keperawatan, STIKes Payung Negeri Pekanbaru, Jl. Tamtama No 6 (penulis 1) \\ email : ysri9232@yahoo.com \\ ${ }^{2}$ Program Studi S1 Keperawatan, STIKes Payung Negeri Pekanbaru, Jl. Tamtama No 6 (penulis 2)* \\ email : iyang.maisi@payungnegeri.ac.id \\ ${ }^{3}$ Program Studi S1 Keperawatan, STIKes Payung Negeri Pekanbaru, Jl. Tamtama No 6 (penulis 3)* \\ email : fitrianiaure182@gmail.com
}

\begin{abstract}
Hipertensi adalah tekanan darah sistolik dan diastolic $\geq 140 / 90 \mathrm{mmHg}$.Tingginya harga obat anti hipertensi tidak sesuai dengan kemampuan masyarakat, beberapa masyarakat mengkonsumsi bawang putih untuk obat hipertensi.Meningkatnya angka hipertensi pada masyarakat juga dapat dicegah dengan cara penganturan gaya hidup seperti pola makan. Tujuan Penelitian ini untuk mengetahui pengaruh edukasi manfaat bawang putih terhadap penderita hipertensi.Jenis penelitian kuantitatif dengan desain pendekatan quasi experimental dengan rancangan post test only with control group. Penelitian ini dilakukan pada Desember 2019 diPuskesmas Karya Wanita Pekanbaru. Jumlah responden sebanyak 24 orang untuk masing-masing kelompok, instrumen penelitian kuesioner dan leaflet dengan melakukan edukasi selama 30 menit.Analisa data yang digunakan yaitu analisa univariat dan bivariate dengan menggunakan Uji $t$ Independent diketahui nilai pvalue adalah sebesar $0.000<0,05$, maka HO gagal ditolak. Sehingga dapat disimpulkan bahwa ada pengaruh pemberian edukasi manfaat bawang putih terhadap keputusan masyarakat mengkonsumsi bawang putih pada penderita hipertensi.Saran untuk masyarakat agar meningkatkan konsumsi bawang putih untuk mengontrol tekanan darah.
\end{abstract}

Keywords : Hipertensi, Bawang Putih, Edukasi, Keputusan.

\section{PENDAHULUAN}

Hipertensi biasanya terjadi pada tekanan darah 140/90 $\mathrm{mmHg}$ atau lebih (Widjadja, 2009). World Health Organitation (WHO) menyebutkan jumlah penderita hipertensi akan terus meningkat seiring dengan jumlah penduduk yang bertambah pada 2025 mendatang diperkirakan sekitar 29\% warga dunia terkena hipertensi. Di Asia penyakit ini telah membunuh 1,5 juta orang setiap tahunnya. Hal ini menandakan satu dari tiga orang menderita hipertensi. Sedangkan di
Indonesia cukup tinggi, yakni mencapai $32 \%$ dari total jumlah penduduk (Tarigan, 2018). Prevalensi hipertensi di Indonesia yang didapat melalui pengukuran pada umur $\geq 18$ tahun sebesar 25,8 persen, tertinggi di Bangka Belitung (30,9\%). Pekanbaru merupakan salah satu kota di Indonesia, Pekanbaru merupakan salah satu kota di Indonesia, prevalensi hipertensi di Pekanbaru tahun 2017 yaitu ada 23.885 orang yang dilaporkan dari semua kecamatan di kota Pekanbaru (Dinas Kesehatan Kota Pekanbaru, 2016). tubuh 
pasien hipertensi, seperti hipotensi, pusing, sakit kepala, mual, letih, batuk kering dan gangguan ginjal. Beberapa obat herbal atau non farmakologi untuk penyakit hipertensi diantaranya adalah daun seledri, mentimun, air kelapa muda, dan termasuk juga bawang putih dapat mengobati penyakit hipertensi tersebut (Izzati, 2017). Terapi hipertensi dapat dilakukan dengan cara farmakologi dan nonfarmakologi. Bawang putih sebagai salah satu ramuan herbal yang dapat dimanfaatkan karena selalu ada dan dapat ditemukan dipasar sebagai bumbu dapur yang digunakan sehari-hari oleh masyarakat. Bawang putih mempunyai efek antihipertensi karena terdapat kandungan Nitric Oxide (NO) didalamnya. (Hevtidayah, 2018).

Bawang putih (Allium Sativum) telah banyak digunakan oleh masyarakat sebagai obat tradisional. Sejak lama, bawang putih dikenal dan digunakan sebagai tanaman yang berkhasiat untuk menyembuhkan beberapa penyakit yang terkait dengan kardiovaskuler (Braunwaid,2010).

Berdasarkan survey pendahuluan yang peneliti lakukan pada bulan September tahun 2019 di Puskesmas Karya Wanita Limbungan Baru, Rumbai dengan melihat data penderita hipertensi di Puskesmas bahwa dari 118 masyarakat di wilayah kerja puskesmas, terdapat 74 lansia yang menderita hipertensi. Rata- rata pasien mengkonsumsi obat, namun pemanfaatan bawang putih sebagai terapi non farmakologis masih kurang. Padahal pemanfaatannya tidak menimbulkan efek samping pada pasien. Berdasarkan fenomena diatas, maka peneliti tertarik ingin mengetahui tentang "Pengaruh Edukasi Manfaat Pemberian Bawang Putih Terhadap Keputusan Masyarakat Mengkonsumsi Bawang Putih Pada penderita hipertensi Di Puskesmas Rawat Inap Karya Wanita Pekanbaru". Tujuan penelitian ini yaitu Untuk mengetahui bagaimana pengaruh edukasi manfaat bawang putih terhadap penderita hipertensi

\section{METODE PENELITIAN}

Penelitian ini menggunakan metode kuantitatif, dengan pendekatan quasi experimental dan menggunakan rancangan post test only with control group. Jumlah popilasi yaitu 74, dan sampel 24 orang kelompok perlakuan (intervensi) dan 24 orang kelompok kontrol. Peneliti menggunakan non-probability sampling dengan metode purposive sampling. Dalam penelitian ini, terdapat instrument yang telah digunakan oleh peneliti yaitu lembar kuesioner, penyuluhan dan ditambah dengan leaflet yang berisi edukasi manfaat bawang putih untuk penyakit hipertensi. Analasi data bivariate menggunakan uji t testindependent 


\section{HASIL DAN PEMBAHASAN}

\section{HASIL}

1. Umur

Tabel 1

Distribusi Responden Berdasarkan Umur padaLansia Puskesmas RI Karya Wanita Rumbai Pekanbaru

\begin{tabular}{|c|c|c|c|c|c|}
\hline No & Umur Responden & Frekuensi & $\begin{array}{l}\text { Presentasi } \\
(\%)\end{array}$ & Kontrol & $\begin{array}{l}\text { Presentasi } \\
(\%)\end{array}$ \\
\hline & Intervensi & & & & \\
\hline 1 & $\begin{array}{l}\text { Lansia awal 46- } \\
55 \text { tahun }\end{array}$ & 1 & $4,2 \%$ & 0 & 0 \\
\hline 2 & 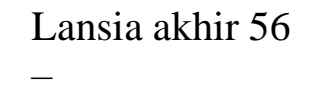 & 15 & $62,5 \%$ & 18 & $75 \%$ \\
\hline \multirow[t]{2}{*}{3} & $\begin{array}{l}65 \text { tahun } \\
\text { Manula }>65 \\
\text { tahun } \\
\end{array}$ & 8 & $33,3 \%$ & 6 & \multirow[t]{2}{*}{$25 \%$} \\
\hline & Total & 24 & $100 \%$ & $100 \%$ & \\
\hline
\end{tabular}

Berdasarkan table 1 dapat dilihat bahwa mayoritas responden penelitian berumur 56-65 tahun (lansia akhir) pada kelompok intervensi berjumlah 15 (62,5\%).
Dan mayoritas responden penelitian berumur 56-65 tahun (lansia akhir) pada kelompok kontrol berjumlah 18 (75\%).

\section{Pendidikan Terakhir}

Tabel 2

Distribusi Responden Berdasarkan Pendidikan Terakhir pada Lansia Puskesmas RI Karya Wanita Rumbai Pekanbaru

\begin{tabular}{cccccc}
\hline No & $\begin{array}{c}\text { Pendidikan } \\
\text { Responden }\end{array}$ & Frekuensi & $\begin{array}{c}\text { Persentasi } \\
(\%)\end{array}$ & Kontrol & Persentasi(\%) \\
\hline 1 & S1 & 1 & $4,2 \%$ & 0 & 0 \\
2 & SLTA/SMA & 12 & $50 \%$ & 23 & $95.8 \%$ \\
3 & SMP & 6 & $25 \%$ & 1 & $4.2 \%$ \\
4 & SD & 5 & $20,8 \%$ & 0 & 0 \\
\hline & Total & 24 & $100 \%$ & & \\
\hline
\end{tabular}

Berdasarkan table 2 dapat dilihat bahwa mayoritas responde yaitu $12(50 \%)$ memiliki pendidikan terkahir yaitu SLTA/SMA dari total seluruh responden 24.
Dan mayoritas responde yaitu 12 (50\%) memiliki pendidikan terkahir yaitu SLTA/SMA dari total seluruh responden 24. 


\section{Tekanan Darah}

\section{Tabel 3}

Distribusi Responden Berdasarkan Tekanan Darah pada Lansia Puskesmas RI Karya Wanita Rumbai Pekanbaru

\begin{tabular}{cccc}
\hline No & Tekanan Darah & Frekuensi & Presentasi \\
& & & \\
\hline 1 & Tahap 1 (140-159) & 20 & $83,3 \%$ \\
2 & Tahap 2 (160-179) & 4 & $16,7 \%$ \\
\hline & Total & 24 & $100 \%$ \\
\hline
\end{tabular}

Berdasarkan table 4.3 dapat dilihat bahwa mayoritas responden menderita hipertensi pada tahap 1 yaitu berjumlah $20(83,3 \%)$ responden.

\section{Keputusan Mengkonsumsi Bawang Putih Setelah Edukasi}

Tabel 4

Distribusi Responden Berdasarkan Keputusan Mengkonsumsi Bawang Putih Setelah Edukasi pada Lansia Puskesmas RI Karya Wanita RumbaiPekanbaru

\begin{tabular}{cccccc}
\hline No & $\begin{array}{c}\text { Keputusan } \\
\text { Mengkonsumsi } \\
\text { Bawang Putih }\end{array}$ & Intervensi & $\begin{array}{c}\text { Persentasi } \\
(\%)\end{array}$ & Kontrol & $\begin{array}{c}\text { Persentasi } \\
(\%)\end{array}$ \\
\hline 1 & $\begin{array}{c}\text { Tidak } \\
\text { Memutuskan } \\
\text { Ya }\end{array}$ & 1 & $4,2 \%$ & 20 & $83,3 \%$ \\
& 23 & $95,8 \%$ & 4 & $16,7 \%$ \\
& $\begin{array}{c}\text { Memutuskan } \\
\text { Total }\end{array}$ & & $100 \%$ & & \\
\hline
\end{tabular}

Berdasarkan tabel 4 dapat dilihat bahwa pada kelompok intervensi mayoritas responden memutuskan untuk mengkonsumsi bawang putih setelah edukasi berjumlah $23(96,3 \%)$ responden, dan pada kelompok kontrol mayoritas responden tidakmemutuskan mengkonsumsi bawang putih sebelum ada nya edukasi berjumlah $20(83,3 \%)$ responden. 


\section{Tabel 5}

Rata - Rata Keputusan Masyarakat Untuk Mengkonsumsi Bawang Putih Setelah Edukasi Penderita Hipertensi pada Puskesmas RI Karya Wanita Rumbai Pekanbaru

\begin{tabular}{cccccc}
\hline $\begin{array}{c}\text { Rata-Rata } \\
\text { Nilai } \\
\text { Keputusan }\end{array}$ & Mean & $\begin{array}{c}\text { StandarDeviasi } \\
\text { (SD) }\end{array}$ & T & Df & pvalue \\
\hline $\begin{array}{c}\text { Perlakua } \\
\mathrm{n}\end{array}$ & 0,17 & 0.095 & - & 46 & \\
\hline Kontrol & 0,96 & 0.093 & $\begin{array}{c}7.977 \\
0.178\end{array}$ & $\begin{array}{c}36.35 \\
2\end{array}$ & \\
\hline
\end{tabular}

Berdasarkan table 5, diketahui nilai pvalue adalah sebesar $0.000<0,05$, sehingga dapat disimpulkan dari nilai $\mathrm{p}$ value bahwa ada pengaruh pemberian edukasi bawang putih terhadap keputusan masyarakat mengkonsumsi bawang putih pada penderita hipertensimaka H0 ditolak. Terlihat bahwa

\section{PEMBAHASAN}

\section{Umur}

Berdasarkan table 4.1 dapat dilihat bahwa mayoritas responden penelitian berumur 5665 tahun (lansia akhir) pada kelompok intervensi berjumlah $15 \quad(62,5 \%)$ dan mayoritas responden penelitian berumur 5665 tahun(lansia akhir) pada kelompok kontrol berjumlah 18(75\%).Hipertensi pada lansia di Amerika mempunyai prevalensi yang tinggi pada usia 65 tahun didapatkan 60-80\% atau sekitar lima puluh juta warga lansia Amerika mempunyai prevalensi tinggi untuk hipertensi. Berdasarkan penelitian yang dilakukan di 6 kota besar seperti Jakarta, Padang, Bandung, Yogyakarta, Denpasar, dan Makasar terhadap usia lanjut (55-85), didapatkan prevalensi hipertensi sebesar 52,5\% (Sarasaty, 2011) dalam (Agustina, 2014).

\section{Pendidikan terakhir}

Berdasarkan table 4.2 dapat dilihat bahwa mayoritas responde yaitu $12(50 \%)$ memiliki pendidikan terkahir yaitu SLTA/SMA dari total seluruh responden 24. Dan mayoritas nilai mean kelompok kontrol lebih tinggi dari kelompok perlakuan (intervensi) yaitu dapat dilihat dari hasil nilai 0,96>0,17, artinya pemberian edukasi sangatberpengaruh terhadap keputusan masyarakat untuk mengkonsumsi bawang putih sebagai obat hipertensi.

responden pada kelompok kontrol yang memiliki pendidikan terkahir yaitu SLTA/SMA berjumlah 23(95,8 \%) . Hasil Riskesdas tahun 2013 dalam Badan Penelitian dan Pengembangan Kesehatan (2013) menyatakan bahwa penyakit hipertensi (tekanan darah tinggi) cenderung tinggi pada pendidikan rendah dan menurun sesuai dengan peningkatan pendidikan.

\section{Tekanan darah}

Berdasarkan table 4.3 dapat dilihat bahwa mayoritas responden menderita hipertensi pada tahap 1 yaitu berjumlah $20(83,3 \%)$ responden. Hipertensi sering juga disebut hipertensi arteri yang mana kondisi dengan tekanan darah diarteri meningkat. Peningkatan ini menyebabkan jantung harus bekerja lebih keras dari biasanya untuk mengedarkan darah melalui pembuluh darah. (Prawiraharjo, 2014)

\section{Keputusan \\ mengkonsumsi bawang putih}

Berdasarkan hasil penelitian yang dilakukan 
oleh responden pada kelompok intervensi mayoritas responden memutuskan untuk mengkonsumsi bawang putih setelah edukasi berjumlah $23(96,3 \%)$ responden dan pada kelompok kontrol mayoritas responden tidak memutuskan konsumsi bawang putih sebelum adanya edukasi berjumlah $20(83,3 \%)$ responden.salah satu olahan bawang putih untuk penyakit hipertensi yaitu fermentasi bawang putih menggunakan ragi,ragi memiliki manfaat untuk menghilangkan bau dari bawang putih tanpa mengurangi khasiat bawang putih.

\section{Rata - Rata Keputusan Masyarakat Untuk Mengkonsumsi Bawang Putih Setelah Edukasi}

Berdasarkan table 4.4, perlakuan posttest yaitu dengan memberikan kuesioner setelah pemberian edukasi yaitu diketahui nilai pvalue adalah sebesar 0.000 $<0,05$, maka H0 ditolak. Keputusan untuk mengkonsumsi bawang putih karena bawang putih memiliki banyak manfaat terhadap hipertensu, salah satunya suplementasi garlic.

\section{SIMPULAN}

Dari hasil penelitian dapat ditarik kesimpulan, yaitu keputusan masyarakat untuk mengkonsumsi bawang putih setelah edukasi yaitu $23 \quad(95,8 \%)$ responden dan diketahui nilai Sig. adalah sebesar $0.000<0,05$, maka H0 gagal ditolak. Sehingga dapat disimpulkan bahwa ada pengaruh pemberian edukasi manfaat bawang putih terhadap keputusan masyarakat mengkonsumsi bawang putih pada penderita hipertensi.

\section{DAFTAR PUSTAKA}

Adhitomo, Indrawan. (2014). Hubungan Antara Pendapatan, Pendidikan, Dan Aktivitas Fisik Pasien Dengan Kejadian Hipertensi. Tesis Pasca Sarjana Universitas Sebelas Maret Surakarta

Amin, Mochammad Al. (2017). Klasifikasi
Kelompok Umur Manusia

BerdasarkanAnalisis Dimensi Fraktal Box Counting Dari Citra Wajah Dengan Deteksi Tepi Canny. Jurnal Ilmiah ISSN 2301-9115

Anggara, Dwi Febby. (2013). FaktorFaktor Yang Berhubungan Dengan Tekanan Darah Di Puskesmas Telaga Murni, Cikarang Barat Tahun 2012. Jakarta timur: Jurnal ilmiah kesehatan Afiah, dkk. (2018). Faktor Risiko Antara Aktivitas Fisik, Obesitas Dan Stres Dengan Kejadian Penyakit Hipertensi Pada Umur 45-55 Tahun Di Wilayah Kerja Puskesmas Soropia Kabupaten Konawe Tahun 2018. VOL. 3/NO. $2 /$ April 2018; ISSN 2502-731X Diakses4 November 2019

Badan Penyelenggaran Jaminan Sosial (BPJS) Kesehatan. (2014). Panduan Praktis Edukasi Kesehatan. Indonesia Divine, Jon. (2009). Program Olahraga Tekanan Darah Tinggi. Yogyakarta: PT. Citra Aji Parama

Hevtidayah, D. R. (2018). Pengaruh pemberian seduhan bawang putih terhadap tekanan darah pada lansia dengan hipertensi $d i$ karang tengah gamping sleman yogyakarta. Naskah Publikasi: Universitas AISYIYAH

Izzati, Wisnatul. (2017). Pengaruh Pemberian Air Rebusan Bawang Putih Terhadap Tekanan Darah Pada Pasien Hipertensi Di Wilayah Kerja Pusesmas Tigo Baleh Kota Bukittinggi Tahun 2017. Afiyah. Vol IV no. 2 Bulan Juli Tahun 2017

Kesehatan, P., \& Pekanbaru, K. (2016).

Dinas Kesehatan Kota Pekanbaru, 1175.

https://doi.org/10.1002/jmri.26010

Kementrian Kesehatan RI. (2013). Riset

Kesehatan Dasar. Indonesia

Kementrian Kesehatan RI. (2014). Departemen

Kesehatan RI. Indonesia

Korneliani, Kiki. (2012). Obesitas Dan Stress Dengan Kejadian Hipertensi. Universitas Siliwangi Tasikmalaya Marhendra. (2016). Pengaruh Letak 
Tensimeter Terhadap

Hasil Pengukuran

Tekanan Darah. Jurnal Kedokteran Diponegoro. Volume 5. :2540-8844

Mohanis. (2015). Pemberian Air Seduhan Bawang Putih Terhadap Penurunan Tekanan Darah

Nandika, Elsa. (2018). Hubungan IMT, Rest Time, Aktifitas Fisik dengan Kejadian Hipertensi Pada Pekerja PT. Lintas Riau Pekanbaru Tahun 2019. Stikes Payung Negeri Pekanbaru

Noerhadi. (2008).

$$
\text { Hipertensidan }
$$

Pengaruhnya Terhadap Organ Tubuh. FIK UNY

Notoatmodjo, Soekidjo. (2012). Metodologi Penelitian Kesehatan. Jakarta: Rineka Cipta

Noviantri, Dinik. (2009). Pengaruh Konsumsi Bawang Putih Terhadap Penurunan Tekanan Darah Pada Penderita Hipertensidi Desa Demangrojo. Yogyakarta

Novitaningtyas, Tri. (2014). Hubungan Karakteristik (Umur, Jenis Kelamin, Tingkat Pendidikan) Dan Aktivitas Fisik Dengan Tekanan Darah Pada Lansia Di Kelurahan Makamhaji Kecamatan Kartasura Kabupaten Sukoharjo. Fakultas Gizi Ilmu Kesehatan Universitas Surakarta

Nuril, Bariroh. (2011). Analisis FaktorFaktor Pengambilan Keputusan Mahasiswa Menetap di Ma"had Sunan Ampel Al-Ali Universitas Islam Negeri (UIN) Maulana Malik Ibrahim Malang. Malang : Skripsi tidak diterbitkan

Prawiharjo, Sarwono. (2014). Ilmu Kebidanan. Jakarta: PT. Bina Pustaka Sarwono Prawirohardjo

Qurbany Zuryani, Toyyiba. (2015). The Benefits Of Garlic (Allium Sativum) As Antihypertension. $\mathrm{J}$ Majority. Volume 4Nomor 3

Rahmawati. (2012.). Potensi Antikoagulan Sari Bawang Putih ( Allium sativum ) Menggunakan Metode Lee-White dan
Apusan Darah, 14(1), 42-48.

Roshifanni, Shofa. (2017). Risiko Hipertensi Pada Orang Dengan Pola Tidur Buruk (Studi di Puskesmas Tanah Kalikedinding Surabaya). Jurnal berkala epidemiologi, vol. 4 no. 3,

september 2016: 408-419

Tarigan, Almina. (2018). Pengaruh Pengetahuan, Sikap Dan Dukungan Keluarga Terhadap Diet Hipertensi Di Desa Hulu Kecamatan Pancur Batu Tahun 2016. Jurnal Kesehatan Vol 11

No 1 Tahun 2018

Widjadja, Rafelina. (2009). Penyakit Kronis. Jakarta: Bee Media Indonesia 